ALPHA N² 28 Julio 2009 (45-63)

ISSN 0716-4254

http://alpha.ulagos.cl

\title{
CUANDO LA MEMORIA POÉTICA DOCUMENTA LA HIS- TORIA NO TODO LO SÓLIDO SE DESVANECE EN EL AIRE. (En torno a Nada queda atrás de Carlos Trujillo y Milton Rogovin) ${ }^{1}$ \\ When poetic memory documents history not everything solid disappears in the air. (Regarding Nada Queda Atrás, by Carlos Trujillo and Milton Rogovin)
}

Sergio Mansilla Torres*

Resumen

Nada queda atrás es un libro de fotografías documentales y de poesía. Las fotografías, tomadas por Milton Rogovin en 1967, en la localidad de Quemchi, Chiloé, son hoy documentos históricos y de denuncia de las condiciones de pobreza en las que entonces vivía la población campesina y pescadora de Chiloé. Los poemas, escritos por Carlos Trujillo 37 años después en los Estados Unidos, son, por su lado, testimonios poéticos de la memoria, personal y colectiva, que suscitan las fotografías; memoria que, a su turno, se vuelve (re)construcción imaginaria de la identidad cultural de Chiloé, vivida por el poeta, como experiencia singular de extranjería y de ausencia. Los textos poéticos son, pues, derivaciones del documento fotográfico, pero, al mismo tiempo, son señas para ver/leer las fotografías como metáforas del Chiloé profundo de ayer y de hoy. Visto así, el libro constituye, literalmente, un documento de cultura y de barbarie: cultura en tanto el libro es un reconocimiento ético y estético a "los olvidados" y barbarie en tanto ese reconocimiento delata historias de postergación y de desigualdad.

Palabras clave: Fotografía documental, poesía chilena, memoria poética, Chiloé, Carlos Trujillo, Milton Rogovin.

\begin{abstract}
Nada queda atrás is a book of documentary photographs and poetry. The photograghs, shot by Milton Rogovin in 1967, in Quemchi on the island of Chiloé, are today documents which record history and denounce the empoverished conditions in which the fishermen and farmers then lived in Chiloé. The poems, written by

1 Trabajo derivado del proyecto Fondecyt $\mathrm{N}^{\circ}$ 1050623, Fondo Nacional de Ciencia y Tecnología de Chile. Una versión resumida de este trabajo se presentó como ponencia en las VIII Jornadas Andinas de Literatura Latinoamericana (JALLA) 2008, realizadas en el mes de agosto en Santiago de Chile.
\end{abstract}




\section{Sergio Mansilla Torres}

Carlos Trujillo, 37 years later in the United Status are, on the one hand, poetic testimonies of the personal and collective memory that the photographs suggest; memories which, in turn, become an imaginary (re)construction of the cultural identity of Chiloé lived by the poet, as a particular experience of foreignity and absence. The poetic texts are, then, derivations of the photographic document, but at the same time they are symbols with which to read/see the photos as metaphors of a profound Chiloé of olden times and today. Seen as such, the book is literally a document of of culture and barbarism: culture as a recognition of the ethics and aesthetics of the "forgotten," and barbarism as that same recognition reveals stories of postponement and inequality.

Key words: Documentary photography, chilean poetry, poetic memory, Chiloé, Carlos Trujillo, Milton Rogovin.

"La fotografía es, antes que nada, una manera de mirar. No es la mirada misma. Es la manera ineludiblemente “moderna” de mirar: predispuesta en favor de los proyectos de descubrimiento e innovación [...] La manera de mirar moderna es ver fragmentos”. Palabras de Susan Sontag (en línea) que, aplicadas a la fotografía que documenta a quienes Martí llamó "los pobres de la tierra”, equivaldría a sostener — me parece — que ésta es (y no podría sino ser) una manera comprometida de mirar huellas de la historia vivida por los sujetos retratados; manera que halla su concreción en el efecto performativo de las imágenes sobre la memoria histórica: quienes miramos hoy esas fotografías nos obligamos a construir una memoria historizada del tiempo de esos otros que nos antecedieron $y$, con el soporte de esta memoria, comprender y trazar las huellas de nuestro propio tiempo, esas mismas huellas que otros, tal vez, lean en el futuro nuestro. Diciéndolo figurativamente, la fotografía documental nos presta ojos para que veamos los interiores de la historia humana de la que formamos parte. Ver "los interiores" de la historia, sin embargo, no sería sino una operación de (re)construcción imaginaria de las vidas de quienes, desde el recuadro fotográfico, nos invitan a comprenderlos en su inmensa humanidad; (re)construcción sostenida, además, sobre la base del poderoso efecto de realidad que provoca la fotografía documental, sobre todo si ésta, como es el caso que aquí nos ocupa, ha sido concebida como testimonio y visibilización de "los olvidados". Hablamos de esas personas que se pierden en la perversa niebla del desprecio y el olvido político de parte de quienes, desde sus privilegiados sitios de poder e indiferencia, determinan las zonas desechables de la historia.

Es, precisamente, lo que acontece en Nada queda atrás, de Carlos Trujillo y Milton Rogovin, un libro que contiene documentación fotográfica y 


\section{Cuando la memoria poética documenta la historia}

literaria de una cierta realidad social marcada por la pobreza y el aislamiento, como es el caso del mundo rural y semirrural del Chiloé de la década de $1960 .^{2}$ La práctica de documentar no acontece por nada. En el caso de Rogovin, es la expresión visible de un compromiso ideológico y político con las clases subalternas; "visible" en sentido literal, pues se expresa como un conjunto de fotografías con un alto grado de documentalidad social (permítaseme el neologismo). El documento fotográfico da paso a una documentación/recreación literaria mediante una escritura que identifica al documento fotográfico; lo sitúa, le recrea su circunstancia original y le otorga, en definitiva, estatus de documento de valor poético y político.

Nada queda atrás reúne 39 fotografías documentales tomadas por M. Rogovin en febrero de 1967 en la localidad de Quemchi y alrededores, Isla Grande de Chiloé; dos, captadas en Ancud, retratan al músico callejero Herminio Remolcoy; más una fotografía que, a juzgar por lo que se puede ver en ella (arquitectura, nombre de la calle), habría sido tomada en Puerto Montt. ${ }^{3}$ Consta el libro, además, de 47 textos de Carlos Trujillo escritos en los Estados Unidos en los años 2004-2005 y que aparecen presentados como "poemas" en la portada del libro. A estos "poemas" hay que agregar un texto inicial de agradecimiento escrito por el mismo Trujillo; una carta autógrafa de P. Neruda dirigida a Rogovin fechada el 13 de noviembre de 1966 en Isla Negra (escrita originalmente en inglés; en el libro aparece en inglés en versión manuscrita facsimilar y su traducción al español); un prólogo escrito por el arquitecto Edward Rojas en el que, entre otras cosas, relata la historia de Nada queda atrás; una especie de prefacio en formato poema firmado por Trujillo; una carta de Rogovin (traducida al castellano por Trujillo) dirigida a Sylvia Huentelicán, una de las personas fotografiadas en 1967 y cuya imagen, junto a la de su pequeña hija, aparecen en la portada del libro, ${ }^{4} \mathrm{y}$ otra breve historia

\footnotetext{
${ }^{2}$ Milton Rogovin y Carlos Trujillo. Nada queda atrás. Santiago: Ograma. Museo de Arte Moderno Chiloé / Isla Grande, 2007. Citaremos por esta edición.

${ }^{3}$ Luis Demarchi, quien acompañó al fotógrafo en 1967, recuerda que Rogovin estuvo "unos 15 días” en Quemchi y que en ese tiempo visitaron distintos lugares aledaños: Guardiamó, Montemar, Colo, Quicaví, isla de Caucahué (y dentro de esta isla Morro Lobos, Quetelquén), isla de Aucar, Choen. Cfr. Re-tratados, video documental (2004). El propio Rogovin anotó en su diario que las fotografías del músico callejero fueron tomadas en Ancud.

${ }^{4}$ La carta de Rogovin no aparece fechada pero indica que ha sido escrita 37 años después de su visita a Quemchi: "Durante los últimos 37 años he mirado mi diario mural y observado la foto de Ud. y su hija” (14). Según testimonio de Trujillo y de dos de los hijos de Milton Rogovin, Ellen y Mark — con quienes conversé en enero del 2008 en Quemchi, con ocasión de la presentación del libro en la Biblioteca Pública del pueblo - esta fotografía ha sido una de las
} 


\section{Sergio Mansilla Torres}

del libro, fechada en Havertown (enero de 2006) relatada, esta vez, por Carlos Trujillo. En la contraportada hallamos una carta de Neruda dirigida a su amiga Lucha en la que le encarga que se ocupe de Rogovin, especialmente en lo que se refiere a hacer que la gente se deje fotografiar por el estadounidense: "El necesita que le hablen a la gente para que no desconfíen de él y se fotografíen de manera natural” (Neruda, contraportada). ${ }^{5}$ Como el lector habrá podido percatarse, estamos ante una obra que amalgama fotografías documentales y textos de distinta naturaleza que van desde la carta personal hasta el poema en sentido estricto.

Rojas, en el prólogo, presenta el libro como "un doble retrato de la verdad". Lo doble radicaría en que estaríamos en presencia de un retrato de dos caras: una constituida por las fotografías y la otra por la palabra: "y así entonces [...] fue surgiendo un libro donde la imagen y la palabra dialogan y navegan, por los canales de nuevos archipiélagos” (11). Lo que Rojas describe como "diálogo" entre imagen y palabra, Trujillo lo imagina como un movimiento pendular que va de la fotografía a la palabra y de la palabra a la fotografía

Van la fotografía a la palabra

Y la palabra a la fotografía

Como el cántaro al agua

Van y regresan una vez

Y otra. Van y regresan

Repletas siempre

"Van la fotografía a la palabra” (13).

más queridas por Rogovin y su esposa (ya fallecida), tanto que por años ha permanecido en el diario mural doméstico del matrimonio Rogovin como una imagen de valor cuasi religioso. La fotografía ha sido antes publicada en diversos medios con el título de "La Madre y el Niño" o “La Madonna”. Cfr. Rojas (Prólogo, 9).

${ }^{5}$ La amiga Lucha de Neruda sería Luisa Chijani, quien, en los años 60, vivía en Mechaico, localidad cercana a Ancud. El dato fue aportado por Medardo Urbina, quien ejerció de editor jefe del libro aquí estudiado, y confirmado por Carlos Trujillo (comunicación personal por correo electrónico: Thu, 28 Aug 2008:08;48;40-0700). Existe, al respecto, una fotografía de autor desconocido, al menos para mí hasta ahora, tomada en Mechaico en 1963 en la que aparece Pablo Neruda, de pie junto a Luisa Chijani y a un niño de nombre César Chijani, al parecer hijo de Luisa, a quien el poeta paternalmente abraza con su brazo derecho. En la misma fotografía, en segunda fila, aparecen Judith González y Mario Chijani. Este documento fotográfico se publicó en el libro Ancud. Imágenes temporales 1900-1965, recopilación hecha por Rodrigo Muñoz Carreño. Por otro lado, hay evidencia testimonial de que Rogovin visitó a Luisa cuando pasó por Chiloé en febrero de 1967. 


\section{Cuando la memoria poética documenta la historia}

La alusión al cántaro yendo al agua remite, desde luego, al refrán popular "tanto va el cántaro al agua que al final se quiebra"; pero el poemaprefacio citado invierte el sentido del refrán: "Va la palabra / Va y regresa / Sin quebrarse nunca” (13). Palabra-cántaro, entonces, que recoge y transporta el agua fundamental de las significaciones poéticas en un incesante ir y venir del texto a la imagen fotográfica y viceversa. Pero, no es un cántaro que se limite a ser simple contenedor de agua; él mismo es contenido: es un agua que no se quiebra nunca. Una manera metafórica de decir que en Nada queda atrás la poesía no puede leerse si no es mirando las fotografías ni éstas verse sino como constituyentes y constitutivas del signo poético. Así, la poesía no puede separarse de una dimensión documental que, en este caso, le sería consustancial de modo que la especificidad estética de los textos queda supeditada, a mi parecer, al efecto documental y testimonial de una realidad humana, de gente pobre, que el libro suscita, reclama y produce.

Las fotografías de Rogovin obedecen al declarado propósito de registrar campesinos chilotes pobres (y objetos y paisajes que atestiguan la vida de estas personas) con el fin de hacer visible su condición social subalterna; pero, sobre todo, con el fin de documentar la humanidad profunda de quienes no tienen lugar en la historia sino como sujetos obliterados por un orden de cosas esencialmente injusto y desigual. "The Rich have their own photographers. I photograph the forgotten ones" ("Los ricos tienen sus propios fotógrafos. Yo fotografío a los olvidados", trad. mía) ha dicho Rogovin, explicitando inequívocamente su compromiso social-político con las clases postergadas. ${ }^{6}$ En su momento, el fotógrafo viaja a Quemchi aconsejado por Pablo Neruda: "Hay una isla grande llamada Chiloé, muy al sur, que yo pienso que es lo que usted busca. Se mantiene asombrosamente intacta, pobre y llena de interés humano" (carta de Neruda a M. Rogovin, 13 de noviembre 1966). ${ }^{7} \mathrm{Al}$ año siguiente, en febrero, Rogovin llega a Quemchi y, gracias a contactos previos establecidos por el poeta - particularmente con el matrimonio Demarchi- pudo realizar, sin mayores dificultades, su trabajo de documentación fotográfica (en el pueblo de Quemchi y alrededores). La lente de Rogovin registró en blanco y negro escenas y cuadros de dramática

\footnotetext{
${ }^{6}$ La frase es el leitmotiv de The Rich have their own photographer, film documental de Ezra Bookstein (2007) USA, 60 min.

${ }^{7}$ En inglés en el original: "There is a big island: Chiloé, in the far South. I think that will do. It is wonderfully untouched, poor and full of human interest” (7). Cito en español según traducción publicada en el mismo libro Nada queda atrás; sin datos acerca del traductor(a) de la carta.
} 


\section{Sergio Mansilla Torres}

humanidad, muy lejos de la mirada aséptica de postal o la del simple registro descriptivo del turista o viajero que se lleva, como recuerdo, imágenes del territorio visitado. ${ }^{8}$

En 2004 llegan a manos de C. Trujillo, poeta chilote residente en Havertown (Pensilvania) las fotografías de Chiloé tomadas por Rogovin. Éstas, que registran un Chiloé de hace casi 40 años atrás, se vuelven material de base para la escritura de un conjunto de textos que, una vez reunidos y unidos a las fotografías, se presentan como "poemas", aunque, en rigor, se trata de textos de factura heterodoxa que toman la forma de crónicas, evocaciones del pasado propio y ajeno, invención de voces atribuidas a los retratados, recreaciones imaginarias de lo que se vivió (y se vive) en el Chiloé de la memoria. ${ }^{9}$ Los textos son, pues, recreaciones literarias de los mundos evocados por las fotografías y, a la vez, testimonios del propio desarraigo del poeta, quien al momento de escribir lleva ya viviendo casi dos décadas en los Estados Unidos. Poesía documental y documentada que nos llama a leer/oír el pasado como una trama de voces que hablan desde el ayer para decirnos que los veamos como sujetos parlantes en su cotidianidad pretérita y, al mismo tiempo, nos veamos en ellos. Poesía y fotografía se unen, entonces, para trazar

\footnotetext{
${ }^{8}$ Del viaje de Rogovin a Chiloé (y a Chile) surgió más tarde el libro Windows That Open Inward. Images of Chile (Ventanas que se abren hacia adentro. Imágenes de Chile), libro de poemas de Pablo Neruda y fotografías en blanco y negro de Milton Rogovin (New York: White Pine Press, 1999). Neruda, en el prólogo de este libro, escribe: "En su carta me hizo una pregunta poco común. Quería fotografiar la verdad. Yo le sugerí que viniera a la parte más austral, a nuestro archipiélago, a Quemchi, a Chonchi, a las playas adormiladas del Sur de las Américas. Él llegó muy pronto, bien equipado y eficiente: norteamericano. Llegó cargado de lentes y cámaras. Él era demasiado para nuestra simplicidad. Yo le recomendé llevar un buen paraguas y él se fue a las aldeas más remotas. Pero él llevaba mucho más que sus cámaras y lentes. Llevaba unos ojos pacientes y buscadores, y un corazón sensible a la luz, a la lluvia, a las sombras” (Trad. Carlos Trujillo, en "Milton Rogovin, Neruda y Chiloé”, en línea). Trujillo, sin embargo, supo de las fotografías de Chiloé de Rogovin sólo cuando Ellen, la hija del fotógrafo, se las hiciera llegar por correo en el año 2004.

${ }^{9}$ Muchos de los textos de Trujillo no responden sino sólo parcialmente a la noción canónica de poema. Es un asunto que en esta oportunidad, sin embargo, no discutiré; salvo mencionar que en este caso la "descanonización" de los “poemas" de Trujillo obedece, a mi entender, a las exigencias que imponen a la imaginación poética el hecho de que la escritura se constituye como negociación con la verdad documental de las fotografías así como la verdad de la memoria vivencial del propio poeta. Queda para otra oportunidad un estudio explícitamente dedicado a los modos en que esta negociación acontece, entendiendo que escribir poesía a partir de fotografías implicaría una mediación particular con el referente último de los textos: en este caso, la realidad del pasado evocado por la memoria y transfigurado en poesía por la imaginación del poeta.
} 


\section{Cuando la memoria poética documenta la historia}

una línea de continuidad entre los retratados y nosotros, los observadores de las imágenes de sus cuerpos y sus enseres. ${ }^{10}$

El “diálogo” imagen-palabra aludido por Rojas toma, en efecto, la forma de un "doble retrato de la verdad" en el sentido de que aquello que podríamos llamar "la verdad de lo humano situado" se la registra, a la vez, con la lente de la cámara fotográfica y con el lenguaje de la literatura. Pero ¿En qué consistiría esa "verdad de lo humano situado"? A mi entender, el libro ofrece una constelación de respuestas. En cuanto al interés humano del que habla Neruda, es verdadero aquello que una fotografía, tomada con la expresa intencionalidad de que sea documento social, registra un momento y lugar determinado, convirtiéndose — con el pasar de los años- en un documento de época que termina interpelando, en un sentido etico-político, la memoria personal y colectiva. Las imágenes de Rogovin hablan de una vergonzosa historia de desigualdad que no puede simplemente ignorarse $\mathrm{y}$, sobre todo, no puede de ningún modo aceptarse como una fatalidad natural. El escenario es el Chiloé de 1967, pero podría ser cualquier otro sitio y otros tiempos en los que haya niños descalzos pobremente vestidos, rostros proletarios endurecidos por el trabajo y por los elementos de la naturaleza: hacheros, zapateros, dueñas de casa de pie en los umbrales de sus modestas viviendas de madera, lancheros de ropas raídas, músicos ciegos mendicantes tocando su acordeón a botones en alguna desolada callejuela de un pueblo olvidado.

Nada queda atrás documenta, asimismo, la verdad de las palabras suscitadas por las fotografías. Palabras que funcionan como poemasdocumentos que dan cuenta de un determinado modo de mirar (de imaginar y de recordar) el pasado asumido por el poeta a la hora de atestiguar su propia doble condición de vidente de las imágenes fotográficas y de memorialista expatriado en los Estados Unidos que se ve impelido a mirar Chiloé - y a mirarse situado en Chiloé- en el espejo nostálgico de su propia memoria del/de su pasado. El ejercicio de textualización y memoria que emprende Trujillo propone un modo de mirar el Chiloé fotografiado por Rogovin que hace que este territorio se dibuje como un espacio de dimensiones metafísicas donde los sujetos humanos y los objetos que expiden el aura de lo humano

\footnotetext{
10 "Vean éstas, mis ropas / Las únicas que tengo / Fueron hechas para alguien / De otro nombre y lugar / Me cayeron a mí / Como cae la lluvia” ("Ropas colgadas en el cordel”, 63). Versos que ilustran la permanente interpelación de los retratados a los lectores-observadores que nos asomamos, a través de la ventana de Nada queda atrás, a la realidad de sus vidas.
} 


\section{Sergio Mansilla Torres}

acontecen como una cotidianidad aparentemente fuera del tiempo, congelados en la imagen fotográfica que captó ese momento irrepetible pero, a la vez, determinados por la historicidad de la propia memoria del escritor: las personas fotografiadas son el recurso clave de la memoria poética con la que el poeta negocia su distancia (y su cercanía) con el pasado chilote, el de los retratados y el suyo propio.

Varias de las personas y objetos representados en las fotografíaspoemas que conforman el libro adquieren dimensiones cósmicas que los sitúan de lleno en el campo de lo simbólico, campo enriquecido por una imaginación surrealista que formula, en clave poética, una absoluta identidad entre lo humano y el universo todo - gesto escritural que nos recuerda la dimensión cósmica del creacionismo de Vicente Huidobro- y que está al servicio de mostrar a los fotografiados como seres en quienes las energías fundamentales del universo hallan su lugar y se manifiestan en plenitud

El pequeño Víctor nació con ojos repletos de cielo y mar.

No fue sorpresa

Que el mar y el cielo se le volvieran uno.

[...]

Con sus ojos abiertos

Se embarcaron en el andar del mundo

Y siguieron su viaje sin preguntas ni quejas

Como pasajeros obedientes y silenciosos

“Doña Isolina, Justo y Víctor” (22-23).

"Tú puedes ir por allí y encontrarte en cualquier cosa con presencias de lo innombrable”, leemos en el poema "Anciana disfrazada de canasto" (27). Trujillo ofrece una imagen de Chiloé como un espacio donde lo misterioso puede estar a la vuelta de la esquina: "si agarras el canasto y lo llevas / tal vez no pueda regresar [la anciana] nunca más” (27), dice el poeta en versos que cierran el poema aludido. En este aspecto, la imaginación poética de Trujillo se hace eco de uno de los rasgos más característicos de la identidad cultural de Chiloé: tierra de mitos y leyendas donde lo misterioso sobrenatural y lo cotidiano natural aparecen indisolublemente imbricados; más todavía si se trata de un Chiloé alojado en la memoria de una época en que aún no había acontecido la secularización de la sociedad chilota, muy avanzada por estos días. ${ }^{11}$

${ }^{11}$ A partir de 1975, Chiloé ha sufrido los efectos de una industrialización acuícola invasiva combinada con la emergencia, en Chiloé, de la cultura mediática global. La práctica masiva del 


\section{Cuando la memoria poética documenta la historia}

La (aparente) intemporalidad de Chiloé se dibuja, por decirlo de algún modo, en consonancia con una suerte de surrealismo propio de un territorio donde, por tradición cultural, la realidad vivida/textualizada por sus habitantes no se reduce al orden de lo real en su forma meramente pragmática y racional, según criterios de racionalidad instrumental del occidente moderno. La poetización de Chiloé, en este sentido, no hace sino atestiguar, no sin un dejo de nostalgia, una tierra y unas gentes acostumbradas a que "lo innombrable" acontezca como una especie de "sobrerrealidad" completamente "natural" en el devenir de los discursos y acciones cotidianas. "Sobrerrealidad" que, desde luego, no aparece retratada en las fotografías de Rogovin, más ocupado en registrar personas en su devenir cotidiano visible que en retratar el mundo misterioso de los seres mitológicos. Pero la imagen de un canasto de junquillo puesto boca abajo sobre el estacón que soporta un grueso cerco de madera, o la de un tronco de árbol quemado que asemeja una escultura vanguardista, o la de una cruz blanca plantada en tierra de cementerio y adornada con corona de papel igualmente blanco (lo que revela que ahí se sepultó a un niño que al momento de fallecer tenía menos de 7 años, un "angelito”), o la imagen de damajuanas vacías que, con sus terrosos canastillos de mimbre, esperan pacientes el vino que las colmará hasta derramarse son, para Trujillo, las huellas de su propio mundo infantil evocado como una ensoñación que pone en práctica textual significaciones de su experiencia cultural más profunda: fantasías poéticas alimentadas por la memoria de sus vivencias chilotas en los tiempos de su infancia y adolescencia y por formaciones ideológicas que se manifiestan como reminiscencias de la tradicional actitud chilota a aceptar lo misterioso (el mito, la leyenda, lo sobrenatural) como un aspecto más de la cotidianidad.

Mirar Chiloé a través de las fotografías de Rogovin no puede sino también ser, como en efecto lo es, un ejercicio de historización testimonial de la memoria que toma la forma de un mensaje político-social. Hallamos varios poemas-fotografías cuyas significaciones trabajan en esta dirección: "El

trabajo asalariado, que en Chiloé había sido hasta entonces una rareza, los mayores niveles de educación formal y el acceso de mensajes mediáticos globales (la cultura de lo transnacional popular) han contribuido a expulsar del devenir cotidiano a seres mitológicos que antes solían convivir con los humanos con una complicidad tal que resultaba, al menos para el observador externo, difícil distinguir los límites entre lo efectivamente vivido como hecho positivo y lo que tiene realidad sólo en el discurso que lo refiere. La secularización ha herido, también, seriamente la cultura religiosa tradicional de Chiloé, relegando, cada vez más, las prácticas religiosas a una esfera especializada y minoritaria de la sociedad isleña. 


\section{Sergio Mansilla Torres}

hachero", "De tiempo, tierra y polvo", "El ciego del acordeón”, "Hilandera anónima”, entre otros. No obstante, quizás el más dramático de los testimonios lo constituye el poema "José Gumercindo Cárdenas, zapatero quemchino”, a quien Milton Rogovin retrató mientras trabajaba en su taller remendando un zapato derecho. Don José era el único comunista de Quemchi a inicios de los años de 1970

Neruda llegó a Quemchi y preguntó al primero que se encontró en la calle

“¿Hay algún comunista en este pueblo?”

Y la brisa del mar que creyó conocer ese afuerino, respondió:

"Sí, poeta.

Hay sólo un comunista en todo el pueblo” (67).

El poema narra la trágica historia posterior. Neruda le envió, en 1972, un libro de su autoría dedicado a don José. Después del 11 de septiembre de 1973, “cuando se volvió peligroso ser comunista”, el zapatero hizo desaparecer el libro, aunque su hija le había insistido que sólo destruyera la hoja de la dedicatoria

— "Hija, tenemos que destruir este libro"

- "Papá, no puedes quemar ese libro de Neruda"

— “Hija, la vida es más importante en este momento"

— "Papá, arranca la hoja con la firma y la dedicatoria. El poeta te lo dedicó a ti”.

Pero el libro regresó con dedicatoria y todo a la nada de donde había salido (67).

Don José nunca se recuperó de esa mutilación y murió unos pocos años después: "Y mi papá se murió también cuatro años después. Creo que se murió de pura pena” (67), declara la hija. Y ni siquiera el día en que lo sepultaron la policía dejó de vigilarlo: "Hasta muerto un comunista se había vuelto peligroso. Los carabineros no le permitieron ir solo ni en su última andada por el pueblo" (67). ${ }^{12}$

\footnotetext{
${ }^{12}$ A juzgar por la información que proporciona María Olga Cárdenas sobre los hechos vividos por su padre, el libro que Neruda enviara a don José habría sido Poemas inmortales (ella habla de una antología). Se trata de una selección de poemas de Neruda publicada en Santiago por Quimantú (noviembre de 1971), una edición popular masiva en homenaje al Premio Nobel de Literatura obtenido por Neruda ese año. En relación con la destrucción del libro, el testimonio
} 


\section{Cuando la memoria poética documenta la historia}

La reconstrucción de la historia de don José Gumercindo, Trujillo la escribió gatillada, se me figura, por la pregunta de base que toda fotografía documental de personas de un modo u otro suscita: ¿Qué habrá sido de las personas de la fotografía? ¿Qué les habrá acontecido después que posaron para el fotógrafo o que fueron sorprendidas por la lente justo para registrar ese instante único que, años más tarde, pasará a ser ojo y ventana para mirar el pasado? Los textos de Trujillo se vuelven ejercicios de historización de las fotografías mismas, alejándolas del riesgo de que éstas se conviertan en simples piezas arqueológicas en el museo de un tiempo ya fenecido. "Estos poemas - nos dice Aurora Camacho - incorporan la visión de Rogovin a la memoria política de los chilenos y de todos nosotros" (inédito). ${ }^{13}$ En efecto, la incorporan desplegando discursivamente un cierto campo de significaciones que la imagen fotográfica sugiere a partir de lo que hemos denominado su documentalidad social y de su consiguiente efecto disparador de memoria política de una historia no precisamente digna de celebrarse.

El trato que Trujillo acuerda con el pasado consiste en hacerlo hablar desde su mismidad pretérita haciendo saltar, no obstante, los límites de lo pretérito para así leer y problematizar el presente de la escritura, lejano en el futuro de ese Quemchi de 1967 (y de la niñez y adolescencia del poeta), pero políticamente comprometido con la urgencia de que el presente actual se lea en y con el pasado: después de todo, lo que hoy vivimos no es sino el futuro efectivamente acontecido que actualizó uno (y anuló a los otros) de los futuros posibles con los que quizás soñaron esas personas que se cruzaron delante del obturador de la cámara de Milton Rogovin en el verano chilote de 1967. Sea como fuere, quienes miraron aquella cámara que en su momento los retrató convirtiéndolos en documentos de época, nos siguen mirando desde su ayer e incitándonos a comprender, aunque sea sólo a través de la pura fantasía poética, su verdad humana.

A su turno, Trujillo (y a su manera, también, Rojas) nos hace ver que esas imágenes de ayer no son sólo imágenes que remitan a otras imágenes. No son, digámoslo, juegos citacionales tan caros a ciertas estéticas postmodernas que disuelven la materialidad de la historia en una interminable cadena de

de María Olga no coincide con la versión literaria de Trujillo: en realidad arrancaron la hoja de la dedicatoria y escondieron el libro. Tiempo después el libro fue recuperado. No dice, sin embargo, si el libro aún permanece en manos de la familia. Cfr. Re-tratados, video documental.

13 "Hallar la luz. Homenaje a Carlos Trujillo en la presentación de su libro Nada queda atrás", texto leído para abrir el acto de presentación del libro realizado en Bartley Hall 1010, Villanova University, viernes 15 de febrero de 2008. (Datos proporcionados por Carlos Trujillo). 


\section{Sergio Mansilla Torres}

citas y referencias. Los textos funcionan como documentos que certifican que cuando la memoria poética de la historia despliega su fuerza evocadora asentada en una intencionalidad política que se niega a colaborar con un orden social desigual e injusto - orden que trabaja, precisamente, para seguir olvidando a los olvidados de siempre- podemos decir, sin temor a equivocarnos, que no todo lo sólido se desvanece en el aire: esa humanidad viviente de ayer es nuestro ayer y una genuina comprensión política de nuestro presente no será nunca posible sin una memoria no reificada del pasado. El ayer no es una abstracción: es una experiencia que se vive como un acto de resistencia política contra el poder de quienes construyeron, a su favor, el olvido de tantos, y de solidaridad con los postergados de ayer (y con los de hoy)

Las noticias en la pared no son noticias de nada. Las fotografías, sólo luces y sombras amontonadas al azar por un pintor ciego y loco. Las hojas del periódico, miserable mueca de papel Decomural en un sitio donde el único texto con sentido son esos ojos que te miran sin acusarte y sin sospechar de tu existencia más allá de la página y la foto.

“Ángeles caídos” (112).

Los periódicos usados como papel mural en las casas pobres de Quemchi y que aparecen retratados en varias de las fotografías de Rogovin (incluidas en Nada queda atrás) contienen noticias y fotografías de 1967 (en realidad, lo que se puede ver corresponde a diarios de 1962 hacia atrás; pero están ahí como parte de la actualidad vivida en 1967). Noticias que hoy "no son noticias de nada", salvo de un hecho de enorme importancia que está ocurriendo ahora mismo, cuando leemos/miramos el libro: nos informan sobre nuestro propio pasado y, al hacerlo, se modifica nuestro propio presente en la medida en que nos obliga a comprender nuestra temporalidad histórica a la luz de los reclamos éticos y políticos de la memoria. Trujillo y Rogovin, cada uno en su momento y con sus métodos de representación respectivos, le otorgan voz y voto a quienes, desde la página de ayer interpelan nuestra memoria: "Yo soy el mundo ¿Dónde se encuentra el mundo que soy yo?” Se pregunta — nos pregunta — la anciana fotografiada en su cocina, sentada con las manos cruzadas sobre el vientre ("Señora sola”, 138). Una respuesta se me ocurre a su pregunta esencial: el mundo que "ella es" se encuentra en nosotros cuando miramos su singularidad de mujer campesina retratada por el ojo testigo de Rogovin.

Digámoslo de otra manera: nosotros somos su mundo porque ella es parte del nuestro. No ella en tanto entidad cuerpo, del cual ni siquiera 
Cuando la memoria poética documenta la historia

sabemos su nombre (a estas alturas nos mirará tal vez desde el libro de los muertos) sino ella en tanto imagen significante que reclama un significado que no sea sólo refrendar la continuidad de la pobreza, del olvido, del abandono. "Mirar es aprender a ver lo que nunca se mira" (112), concluye el poema antes citado. Lección descarnada que nos pone ante el inexcusable deber de reconocer, valiéndose de la imagen y la palabra en diálogo, a quienes la historia oficial relega, cada vez que puede, al cajón de los trastos desechables.

\section{EPÍLOGO TESTIMONIAL}

El jueves 10 de enero de 2008 tuve la oportunidad de asistir a la presentación formal del libro Nada queda atrás, que se realizó en la Biblioteca Pública de Quemchi, con la atenta y cariñosa recepción de Teolinda Higueras, su directora. Para la ocasión vinieron especialmente desde los Estados Unidos Carlos Trujillo, Ellen y Mark Rogovin, hijos de Milton, en representación del fotógrafo quien, a sus 98 años, se le hacía imposible viajar a Chile. Lo más humanamente significativo, sin embargo, fue que se contó con la presencia de algunas de las personas que fueron fotografiadas, en ese febrero de 1967, por Rogovin y que están aún vivas. Juan Bautista Teihue Tongol "el hachero", acompañado de su hijo, se reencontró con su propio pasado, según el mismo relató, al mirarse en la fotografía en la que se le ve joven y de pie mientras mantiene afirmada su hacha en posición vertical con ambas manos. También estuvo Sylvia Huentelicán, ahora una mujer madura, cuyo rostro y cuerpo delata las durezas de una vida que no ha sido fácil para ella; pero en 1967 era una joven madre cuyo retrato años más tarde —y ella sin saberlo- se repartiría por diversos lugares del mundo. Un día radiante de febrero de ese año, a eso de las 11 de la mañana (según testimonio de ella misma), estando Sylvia en la puerta de su casa, Rogovin le solicitó posar para algunas fotografías. En una de ellas fue retratada junto a su pequeña hija Rosa Elba Aquintui Huentelicán, fallecida siete años después en un accidente automovilístico en Puerto Montt. Se trata de una de las fotografías más bellas, tanto que el fotógrafo y su familia la convirtieron en una de sus fotografías más queridas: "Durante los últimos 37 años he mirado el diario mural y he observado la foto de usted y su hija —le escribe Rogovin a Sylvia Huentelicán- [...] Recuerdo cuando iba caminando por la bahía y vi su casa; la puerta estaba abierta y miré hacia adentro y vi a una hermosa mujer y su 


\section{Sergio Mansilla Torres}

hija. Usted me permitió tomarle la foto que ahora aparece en libros y revistas alrededor del mundo" (14). ${ }^{14}$ Asimismo, estuvieron presentes Lindana Fomann, hija de Ivar Fomann y Lindana Soto Corbet, ambos fotografiados por Rogovin en 1967 (Lindana Fomann para entonces tenía 20 años); también María Olga Cárdenas Vidal, hija de José Gumercindo Cárdenas, el zapatero comunista.

De extraordinario valor informativo y humano resultó ser el documental Re-tratados, de Luis Rafael Tapia Charme (Cicleto Tapia), exhibido en esa oportunidad como parte de la presentación. Tapia se dio a la tarea de ubicar a los retratados por Rogovin, que aún sobreviven, e indagar en la historia de sus vidas desde 1967 a 2004 (consignemos que Rogovin no registró los nombres de las personas fotografiadas). ${ }^{15}$ Dio con Juan Bautista

\footnotetext{
${ }^{14}$ Cuando Cicleto Tapia da con Sylvia Huentelicán, Ellen Rogovin le escribe una conceptuosa nota: "Estoy tremendamente feliz de que Luis (Cicleto) te haya encontrado. Yo soy la hija mayor de Milton Rogovin. Cuando tú eras una joven madre viviendo en Quemchi con tu marido y tu pequeña hija, mi padre te fotografió... Tu fotografía empezó a ser exhibida con mucha frecuencia. No puedes imaginar cuánta gente se ha detenido frente a tu foto a mirar a ti y a tu hija y a preguntarse qué habrá sido de tu vida. La gente comenzó a llamarte La Virgen (Madonna). Al pasar los años, Milton puso en su casa la fotografía de ti y tu hija. Se volvió su fotografía favorita. Años después, cuando mi madre estaba muriendo de cáncer, ella le pidió que la fotografía de la madre y su hija estuvieran al lado de ella en su pieza. Ella adoraba la fotografía, y la fotografía le dio paz y tranquilidad en su último momento. Mis padres estuvieron juntos durante 62 años”. Fragmento traducido y publicado por Carlos Trujillo, “Neruda, Rogovin, Cicleto y Chiloeweb” (en línea).

${ }^{15}$ Cuando Trujillo recibió el conjunto de fotografías de parte de Ellen, las que más tarde serían parte de Nada queda atrás, sólo pudo reconocer a José Herminio Remolcoy, músico callejero ciego, originario de la isla de Puqueldón. "El músico de la fotografía es la única persona a la que conocí de todas las fotografiadas. Siempre lo veía sentado en la calle Blanco [en Castro], tal como dice el poema, en los mismos sitios que menciono. Pero el tiempo me ha hecho olvidar si siquiera alguna vez supe su nombre. Pero estoy casi completamente seguro que así fue. Cuando Aydé [su esposa] y yo empezamos a mirar las fotografías que nos mandó Ellen Rogovin en busca de algún rostro conocido, ése fue el único que conocimos, puesto que ese señor estuvo diariamente tocando su acordeón en esa calle por muchísimos años. Cuando me puse a investigar su nombre, lo primero que hice fue llamar a mis parientes en Castro y en Punta Arenas. Entonces, una de mis hermanas me contó que posteriormente lo habían visto en Punta Arenas y que se enteraron de que cuando se puso más anciano, un hijo suyo lo había llevado a vivir con él. Pero no podía hallar ninguna pista del nombre, hasta que puse el poema y la fotografía en www.chiloeweb.com (el único poema publicado como adelanto) y se dio la coincidencia de que un amigo mío, Luis Mardones, no sólo recordaba su nombre sino que también me contó que al terminar cada jornada don Herminio dejaba su acordeón en casa de don Manuel Ballesteros, un recordado comerciante castreño que también fue dueño de la "Francisquita”, una preciosa lancha que hacía cabotaje entre Castro y Puerto Montt. Bueno, don
} 


\section{Cuando la memoria poética documenta la historia}

Teihue Tongol, quien reside en una zona rural de Quemchi; con María Legilia Nahuelquén Naguil, una niña en 1967 y que aparece retratada junto a sus padres y sus tres hermanas, en la localidad de Choen, comuna de Quemchi (reside hoy en el mismo lugar); con María Raquel Soto Tocol, quien en 1967 tenía 15 años y aparece retratada junto a su abuela Candelaria Tocol (hoy María Raquel reside en Santiago); con Sylvia Huentelicán, hoy residente en Puerto Montt. Logró, asimismo, ubicar a familiares directos de algunos de los retratados ya fallecidos: Justo Vidal Vidal, de la isla de Caucahué, pariente directo de Isolina Vidal Barrera, Justo Vidal y Víctor Vidal, niño este último, los tres retratados en una misma fotografía. Por testimonio de Justo "hermano de crianza" de Víctor, nos enteramos de que éste falleció muy joven en un accidente en el mar. El video documental de Tapia muestra, también, los testimonios de Lindana, hija del matrimonio Fomann-Soto, y de María Olga, hija de José Gumercindo Cárdenas.

Las historias de los "re-tratados" son de enorme peso humano, una realidad de vida (trágica en muchos casos) ante las cuales la fotografía y la poesía parecen signos débiles, bosquejos de mundo que no alcanzarían sino a registrar fragmentos mínimos de la insondable complejidad de las vidas de quienes no son ni han sido los privilegiados de la historia. Pero tal debilidad es ilusoria: las fotografías, la poesía, el video documental convocan un trozo de realidad humana insoslayable, que ha sido sacado de la invisibilidad política y que ha pasado a formar parte de una cierta memoria histórica que reivindica el compromiso de no olvidar a los que en vida fueron "los olvidados”.

Nada queda atrás es un libro que colisiona con la extendida idea de que el pasado es "tan irrecuperable como incorregible: no hay quien nos lo devuelva ni es sensato quererlo diferente de lo que fue [...] y lo que se marchó sin remedio ya no puede ser modificado” (Cordua, 157). Si hay algo que experimentamos como "realidad necesaria" es, justamente, la imposibilidad de cambiar el pasado. Pero, como la misma Cordua señala, "ni la más implacable necesidad es capaz de suprimir, por sí sola y de una vez, todas las posibilidades humanas” (157). Y el pasado no es la excepción. El giro

Manuel era tío de Luis Mardones, así que por ese camino llegué al nombre. [...] Una cosa más que me parece extraordinaria es que Milton Rogovin recuerda haber tomado esas fotos en Ancud, y así lo anotó en su diario. Eso crea otro misterio puesto que don Herminio llegó a Castro desde Puqueldón, pero por lo visto, y si le creemos a las notas del fotógrafo, también hacía sus temporadas en las calles de Ancud”. (Trujillo, mensaje electrónico personal 16 de mayo de 2008:13;43;59 PDT). 


\section{Sergio Mansilla Torres}

imaginario-poético que en los poemas de Trujillo toman las fotografías de Rogovin no es sino una de las maneras de tratar con el pasado, para convertirlo en materia (re)construida por la memoria humana: el hecho de que el pasado ya dejó de ser materialidad viviente tal como lo fue en su momento, no se contradice con el hecho de que recordarlo - por más fragmentario, por más ficcional que sea el recuerdo- constituye una dimensión insoslayable del presente, del contrato de inteligibilización que hacemos con nuestro propio tiempo para hallarle sentido y razón.

Es insoslayable, sin embargo, sólo si la memoria se la concibe como un dispositivo para ver en el pasado una autoridad que, de un modo u otro, gobierna nuestro presente. Aunque en esto haya o pueda haber matices muy diferenciados y aun contradictorios: desde la concepción del pasado como tradición irrevocable que alimenta actitudes y pensamientos conservadores 0 , incluso, abiertamente reaccionarios y fundamentalistas, hasta la idea de un pasado que opera como un escenario de extrañeza dialéctica que impele a nuestro presente a hablar con el lenguaje de la transformación radical de la historia, haciendo del tiempo pretérito la llave que abre la puerta de un futuro que no ha de verse y construirse sólo como simple continuidad de un orden de cosas contrario a la justicia y a la libertad. Nada queda atrás no es precisamente una alabanza a la tradición chilota, si por tradición entendemos aquella memoria que monumentaliza y petrifica el pasado y cuya continuidad histórica acontece como una ritualidad que machaca las conciencias alejándolas de la crítica radical. El trato con lo pretérito en el libro, selectivo como todo ejercicio de memoria, acontece como un "viaje" a 1967; un desplazamiento imaginario hacia una suerte de Ítaca temporal a la que nunca se llega en realidad, pero el viaje en sí mismo es lo que importa: ${ }^{16}$ es un ejercicio discursivo de "resurrección" de los vivos de ayer, por el que vuelven, a través de la poesía, a tener voz, a hablar como si los cuerpos estuviesen todavía ahí: es el modo como "los olvidados” desmienten tal condición.

Pero, eso ocurre porque hubo un fotógrafo, comprometido con la utopía de una sociedad socialista, que los registró en su cotidianidad y lo hizo con un

\footnotetext{
${ }^{16}$ Tengo en mente, por cierto, el conocido y bello poema “Ítaca” de Constantino Kavafis. En Chile este poema se conoce principalmente a través de la traducción de Miguel Castillo Didier. El músico chileno Patricio Anabalón musicalizó en 2003 la versión castellana de Castillo Didier, junto a una decena de textos de poetas griegos antiguos y modernos. Ítaca. Poetas griegos musicalizados. Santiago: Sello Alerce, 2003, CD. El disco incluye grabación de lectura en griego del poema, realizada por el propio traductor.
} 


\section{Cuando la memoria poética documenta la historia}

propósito sociopolítico: mostrar a quienes nadie ve; nadie, salvo que no sea quienes - movidos por su vocación de compromiso con los postergadostrabajan para documentar (y cambiar en definitiva) la historia obliterada de los olvidados. Ocurre, también, porque hubo un escritor que, apoyándose en la fotografía, recorre su propio pasado, que —a su manera - forma parte también de la realidad fotografiada. Así, la poesía se vuelve una práctica textual en la que se construye un yo que hace hablar a las fotografías a la vez que es hablado por ellas. Pero el diálogo que revive a los muertos, no termina aquí. El film documental de Cicletto Tapia otorga a los ausentes, a los que no aparecen en ninguna tribuna del poder, una presencia testimonial potente, que nos obliga, por decirlo de algún modo, a no desconectar las imágenes de los cuerpos con sus cuerpos reales, vivientes. A no olvidar que las voces de la poesía, de esta poesía, serían imposibles sin las voces de quienes vivieron y murieron o de quienes aún viven contra el olvido. El pasado se puede, entonces, corregir. No en cuanto a modificar los hechos materiales del ayer. Sí, en lo que respecta a las significaciones de esos hechos en la medida en que el recuerdo —el sector de realidad recordado, en rigor- se lo viva como radical experiencia de compromiso con la más esencial humanidad de "los olvidados”

¿De dónde vinieron los que llegaron alguna vez quién sabe de dónde?

¿De dónde vinieron los que llegaron, los que nos precedieron en su aquí y su ahora en este mismo aquí o casi en este mismo aquí, en otro ahora que se ha vuelto sombra, oscuridad, desconocimiento, ojo quebrado, oreja sorda, corazón revuelto?

[...]

¿Cuáles los pasos que los trajeron a este aquí donde vivimos y nos preguntamos por ellos?

“¿De dónde vinieron?” (187).

Preguntas como éstas cierran el libro y son la mejor evidencia de que el pasado no está ni estará nunca clausurado. Preguntas de respuesta abierta, o de no respuesta quizás, pero cuya formulación por sí misma delata otra implacable necesidad: que la realidad vivida, sea por otros o por nosotros, requiere ser permanentemente revisada y corregida, porque lo vivido sí es una realidad revisable, interpretable y corregible. Más, todavía, si esto se torna un deber de solidaridad con quienes nos antecedieron. El futuro, entonces, bien podríamos concebirlo como aquella temporalidad en que proyectamos lo posible (y lo imposible también) y que nos invita, nos exige en realidad, a revisar y corregir la memoria del pasado en tanto vivencia humana concreta; 
Sergio Mansilla Torres

pasado éste que, para efectos de una crítica radical de las representaciones históricas, es un imperativo que no podemos ignorar a la hora de diseñar nuestras tareas de compromiso y responsabilidad solidaria con la comunidad humana de la que formamos parte.

\author{
Universidad de Los Lagos* \\ Departamento de Humanidades y Artes \\ Centro de Estudios Regionales (CEDER) \\ Casilla 933, Osorno (Chile) \\ smansill@ulagos.cl
}

\title{
BIBLIOGRAFÍA
}

BOOKSTEIN, Ezra. The Rich Have Their Own Photographers. Film documental, 2007, USA, 60 min.

CAMACHO, Aurora. "Hallar la luz. Homenaje a Carlos Trujillo en la presentación de Nada queda atrás”. Villanova University, viernes 15 de febrero de 2008 (inédito).

CORDUA, Carla. “Tratando con el pasado”. Ideas y ocurrencias. Santiago: RIL, 2001:157-169.

KAVAFIS, Constantino. "Ítaca”. Ítaca. Poetas griegos musicalizados. Patricio Anabalón y Miguel Castillo Didier. Santiago: Sello Alerce, 2003, CD de audio.

MUÑOZ CARREÑO, Rodrigo. Ancud. Imágenes temporales 1900-1965. Ancud: La Bauda, 2007.

ROGOVIN, Milton; TRUJILlO, Carlos. Nada queda atrás. Santiago: Ograma. Museo de Arte Moderno Chiloé/Isla Grande, 2007. ${ }^{17}$

ROJAS, Edward. "El doble retrato de la verdad". Prólogo a Nada queda atrás. Chiloé: Museo de Arte Moderno/Isla Grande (2007):8-11.

SONTAG, Susan. "La fotografía, breve suma", en La Jirafa con Tacones. Revista de Comunicaciones $\mathrm{N}^{\circ} 12$, Año II (junio-agosto 2006). Versión PDF en línea: www.fusion3.com.ar/lajirafacontacones/numero12/N12COMUNICACION.pdf [13 mayo 2008].

TAPIA, Luis (Cicleto). Re-tratados. Film documental, 2004, Chile, 47 min.

\footnotetext{
${ }^{17}$ El libro se publicó en Santiago y se manufacturó en Impresiones Ograma Ltda. Pero esta información no aparece consignada en el libro mismo. (Datos proporcionados por Medardo Urbina).
} 
Cuando la memoria poética documenta la historia

TRUJILLO, Carlos. “Neruda, Rogovin, Cicleto y Chiloeweb”, en: http://www.chiloeweb.com/datos/noticias/Noticias.asp?No_Id=200429 9002. Artículo publicado el 25-10-2004. [20-05-2008].

TRUJILLO, Carlos. "Milton Rogovin, Neruda y Chiloé”, en: http://www.chiloeweb.com/datos/noticias/Noticias.asp?No_Id=200419 3002. Artículo publicado el 11-07-2004. [20-05-2008]. 